\title{
EVALUATION AND IDENTIFICATION OF WALNUT HEARTWOOD EXTRACTIVES FOR PROTECTION OF POPLAR WOOD
}

\author{
Seyyed Khalil Hosseini Hashemi ${ }^{\text {a,* }}$ and Ahmad Jahan Latibari ${ }^{\text {a }}$ \\ Walnut (Juglans regia L.) heartwood extractives were identified and their \\ potential for protection of poplar wood was evaluated. Test specimens \\ were prepared from poplar wood (Populus nigra L.) to meet BS \\ 838:1961 requirements. Samples were impregnated with heartwood \\ extractive solution $(1.5,2.5$, and $3.5 \% \mathrm{w} / \mathrm{w}$ in ethanol-toluene), followed \\ by 5 hours vacuum desiccator technique to reach complete saturation. \\ Impregnated specimens were exposed to white-rot fungus (Trametes \\ versicolor) for 14 weeks according to BS 838:1961 applying the kolle- \\ flask method. The weight loss of samples was determined after exposure \\ to white-rot fungus. The highest weight loss (36.96\%) was observed for \\ untreated control samples and the lowest weight loss $(30.40 \%)$ was \\ measured in samples treated with $1.5 \%$ extractives solution. The \\ analyses of the extracts using GC/MS indicated that major constituents \\ are benzoic acid,3,4,5-tri(hydroxyl) and gallic acid (44.57\%). The two \\ toxic components in the heartwood are juglone $(5.15 \%)$ and $2,7-$ \\ dimethylphenantheren (5.81\%).
}

Keywords: Walnut heart wood extractives; Trametes versicolor; Weight loss; Gallic acid; Juglone; 2,7dimethylphenantheren

Contact information; a: Agriculture Research Center, Islamic Azad University, Karaj Branch, P. O. Box 331485-313, Karaj, Iran. 'Corresponding author: hashemi@kiau.ac.ir

\section{INTRODUCTION}

One of the promising strategies to slow down the decay and deterioration of wood structure is to rely upon durable wood species. Usually, heartwood of most species contains higher levels of extractives compared to sapwood, and some natural durability exists against microorganism in some timbers. The heartwood of species, such as western red cedar (Thuja plicata), redwood (Sequoia sempervirens), teak (Tectona grandis), black locust (Robinia pseudoacacia), cypress (Cupressus sempervirens), walnut (Juglans nigra), osage orange (Maclura pomifera), and ebony (Diospyros lotus), are very resistant to decay (Reyes-Chilpa et al. 1998; Gottlieb and Yoshida 1989; Rudman 1963; Thevenon et al. 2001; Waterman 1946). In this respect, natural compounds extracted from various woods especially heartwood have been proven to impart antifungal properties in some woods. Examples of such compounds are cinnamaldehyde (Wang et al. 2005), $\alpha$-cadinol (Chang et al. 1999), carvacrol (Kai 1991), Tmuurolol, T-cadinol, c-cadinene (Kondo and Imamura 1986), cryptomeridiol (Morita et al. 1997), tropolones (Hart 1989), pinosylvin (Schultz et al. 1990), oxyresveratrol, dihydromorin (Schultz et al. 1995), gallic acid (Kishino et al. 1995) and ferruginol (Rudman 1965). Therefore, in recent years, the wood preservation industry has preferred natural and vegetable-based chemicals for wood treatments. Some extractives contain tannin or exhibit toxic effects against biotic agents, 
and are preferred for protection of wood or wood-based materials against microorganisms (Schultz and Nicholas 2000).

However, these species are not widely available, and their utilization is limited and even in some cases prohibited (Thomasson et al. 2002). Consequently, consumers ought to utilize wood from other species, applying impregnation by an effective preservative that is environmentally acceptable (Thevenon et al. 2001).

Chemical preservatives impart a negative impact on our environment, including malabsorption, unsuitable fixation, and leaching of arsenic containing compounds from CCA treated wood, as well as transfer to human beings from playground equipment, thus presenting risks to children's health (Lebow and Tippie 2001; Stevanovic-Janezic et al. 2001), etc. Also, the application of some treated wood may be excluded in housing and other venues due to the emission of toxic vapors, difficulty in handling, allergic effects for animals and people, as well as inadequacies in dealing with related environment issues (Thomasson et al. 2002).

The genus Juglans of the family Juglandaceae contains more than 25 species distributed throughout many regions of the world. Juglans regia L., which is the native of Central Asia extending from Xinjiang province, western China, Kazakhstan, Uzbekistan, and southern Kirghizia to Nepal, Tibet, northern India, and Pakistan through Afghanistan, Turkmenistan, and Iran to portions of Azerbaijan, Armenia, Georgia, and eastern Turkey (McGranahan and Leslie 1991), produces durable wood which has lasted for centuries in ancient buildings and in common application such as home furniture. It is envisioned that the extracts of walnut wood powder exhibits potential as an environmentally friendly and natural wood preservative. It has been acknowledged that the extraction yield of this wood is high, producing low cost material for wood preservation (Thevenon et al. 2001; Steber 2000; Da Costa et al. 1958; Rudman and Da Costa 1959).

Walnut (Juglans regia L.) is a commercial hardwood species growing in the north of Iran. Walnut heartwood is dark brown and often veined with excellent drying and shrinkage characteristics and strength properties. As a result it has found a wide range of applications from rustic furniture, sculpture, fine joinery, carving, and decorative veneering, to outdoor use such as decking and structural applications. Such processing generates vast quantities of residues. Walnut heartwood is classified as a durable wood (Scheffer and Cowling 1966; Scheffer and Morrell 1998) which has been related to the presence of phenolic compounds such as flavonoids, naphtoquinones, and hydrolysable tannins (Gupta et al 1972).

Detailed phytochemical and pharmacological studies have shown that the extractive is mostly juglone, which can cause blackening, blistering, and peeling of the skin. It also acts as a tranquilizer and sedative (Bhargava 1967; Westfall et al. 1961), shows antitumor activity (Bhargava and Westfall 1968), and it is fungi toxic, antibiotic, and allelopathic (Soderquist 1973). The wood of black walnut contains appreciable amounts of gallic acid as well as ellagic acid, glucose, and a dark violet polymer (Gupta et al. 1972; Seshadri 1973). Ellagic acid is a sedative and tranquilizer and has antitumor activity (Bhargava and Westfall 1968).

The objective of this study was to evaluate the toxicity potential of walnut heartwood extractives, identify the components present in the extracts, and investigate whether such extract could be successfully used as preservative to protect non-durable 
poplar wood against white-rot fungal (Trametes versicolor). Also it was of interest to examine the effect of heartwood extractives on the weight loss of poplar wood, a common wood for rural construction to improve its performance for applications such as decking, carrier and roof poles, pile and truss, joinery and furniture, and box making.

\section{EXPERIMENTAL}

\section{Materials}

Poplar wood (Populus nigra L.) was selected according to TS 2476, as defectfree, clear, and normally grown (without zone lines, reaction wood, decay, and insect damage, or fungal infection) wood from a plantation in northern city of Tonekabon, Iran located on fertile lands at the elevation of 20 meters above sea level. The annual precipitation of this area is usually about $1100-1500 \mathrm{~mm}$. Walnut wood (Juglans regia L.) was collected from a forest in the northern city of Ramsar, Iran located at an elevation of 640-1000 meters above sea level with annual precipitation of 934-1616 mm.

\section{Wood Extraction}

Walnut wood powder (flour) was soxhlet extracted according to ASTM D 110796. Wood powder was filled in the extraction apparatus and successively extracted with ethanol-toluene $(2: 1 \mathrm{~mL}, \mathrm{v} / \mathrm{v})$ until a colorless solution was obtained. Usually $6-8$ hours was required to complete the extraction. The solvents (ethanol-toluene) were evaporated at $40^{\circ} \mathrm{C}$ in a rotary evaporator to reach a viscous solution in the flask, and then dried under nitrogen gas to produce powder.

\section{Toxicity Screening}

To evaluate the toxicity potential of the extract, $25 \mathrm{mg}$ (dry powder) sample of extract was dissolved in either $2 \mathrm{~mL}$ mixture of ethanol-toluene or toluene individually and then filtered using a syringe filter and poured into a glass vial. The media containing malt extract agar (MEA) was sterilized in an autoclave at $120^{\circ} \mathrm{C}$ for 20 minutes, and then the solution containing sample of extract was poured into the $75 \mathrm{~mL}$ of sterile media using micro-sampler. Then the media was poured into three petri plates. Five concentrations of extract solution, ranging between 0 to $0.15 \mathrm{mg} / \mathrm{mL}$ (Table 1) were added to petri plates and thoroughly mixed with media. Each test was duplicated in three replicates. The plates were cooled in a sterile hood and inoculated with $0.5 \mathrm{~cm}$ round plugs of Trametes versicolor (TV) fungus mycelia, which were introduced into the center of the petri plate using the tip of pasture pipet. Inoculated plates were placed in $23^{\circ} \mathrm{C}$ and $75 \%$ relative humidity without light. Fungal growth was monitored daily measuring the radial growth and calculating the percentage of area that was covered by fungus in each plate. The toxicity level was determined as the extract concentration which exhibited the lowest fungal growth as specified in modified method by Nzokou and Kamdem (2002).

\section{Preparation of Test Specimens}

Wood specimens were randomly selected. Rough boards at $30 \mathrm{~mm}$ thickness were tangentially sawn and then stored at $20^{\circ} \mathrm{C}$ and $65 \%$ relative humidity for 2 months to 
reach $12 \%$ final moisture content. Then test specimens were cut from these rough boards (Fig. 1) having dimensions of $50 \times 25 \times 15 \mathrm{~mm}$ for weight loss according to BS $838: 1961$. Specimens were randomly used in our experiments.

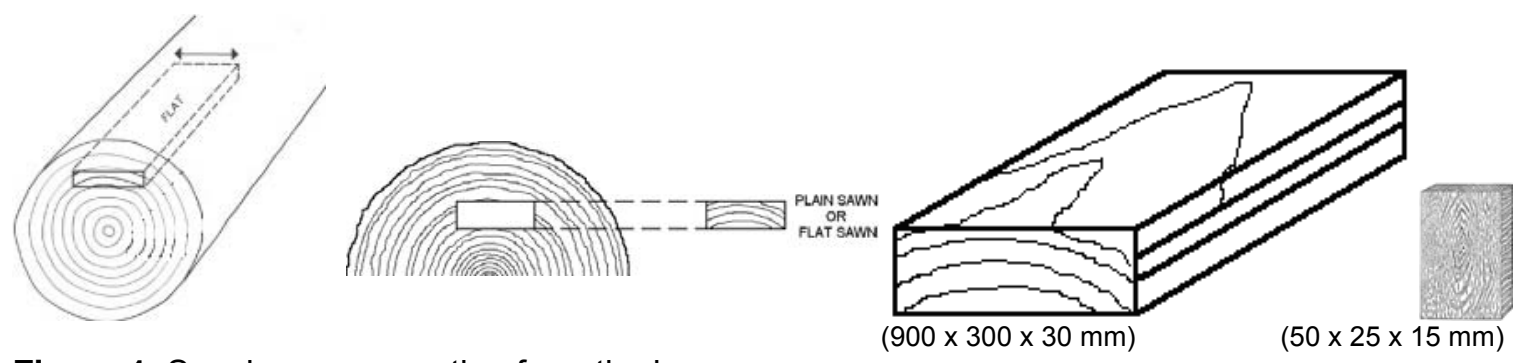

Figure 1. Specimen preparation from the log

\section{Test Specimens Impregnation}

Specimens were treated applying solutions of walnut heartwood extracts in ethanol-toluene at concentrations of $1.5,2.5$, and 3.5\%. These had shown higher toxicity in previous tests, and they were above the relative threshold. To reach uniform distribution and absorption of the solution, specimens were submerged in the treatment solution applying 0.78 bar (11.3 psi) vacuum in vacuum desiccators for 5 hours. Specimens were then wiped to remove the excess solution from the surface and weighed to determine the amount of treating solution absorbed.

Treated specimens were stored under $65 \%$ relative humidity and $20{ }^{\circ} \mathrm{C}$ temperature for 4 weeks to reach the equilibrium moisture content of $12 \%$. Before and after impregnation, samples were oven dried to $0 \%$ moisture content. After cooling in desiccators, the oven dry weights of the specimens were measured. The retention ratios of chemicals $(R \%)$ were calculated as follows,

$$
R(\%)=\frac{M d i-M d}{M d} \times 100
$$

In this equation, $M d i$ is the oven-dry mass after impregnation (grams) and $M d$ is the oven-dry mass before impregnation (Table 3).

\section{Decay Test}

Decay tests were conducted in accordance with BS 838:1961 as applied by the kolle-flask method for 14 weeks exposure to Trametes versicolor. The fungus was grown and maintained on malt extract agar (MEA). The medium was sterilized for $30 \mathrm{~min}$. at $125^{\circ} \mathrm{C}$ and cooled to room temperature before inoculation. Test kolle flasks were prepared with $60 \mathrm{~mL}$ of MEA and closed with a cotton cap. The filled kolle flasks were then loosely capped and autoclaved for $30 \mathrm{~min}$. at $105 \mathrm{kPa}$ and $125^{\circ} \mathrm{C}$. After cooling the kolle flasks, the plug was cut from the actively growing edge of a 7-day old MEA culture of white-rot fungus and placed into the kolle flask. After the next seven days the treated and control specimens (Populus nigra L.) were placed on the top of the two small glass legs in each kolle flask (Fig. 2), parallel to opposite corners of the mycelia plug. 
Each inoculated kolle flask was then incubated at $23{ }^{\circ} \mathrm{C}$ and $75 \%$ relative humidity until the specimens were heavily colonized by fungus. All decay tests were performed on specimens from each group of treated specimens impregnated with different concentrations of extractives solution. For either of three concentrations of extractives solution $(1.5,2.5$, and 3.5\%) three replicates were tested. We realize that three replications are not sufficient for this case. However, our limitation on the availability of extract necessitated lesser number of specimens than usually required. The labeled test specimens were placed on a screen tray and oven dried to $0 \% \mathrm{MC}$. The specimens were weighed to the nearest 0.01 gram and recorded as un-decayed weight (W1). At the end of the exposure period, the exposed test specimens were removed from the kolle flasks, their surfaces were carefully brushed, and then they were oven-dried to $0 \% \mathrm{MC}$. The specimens were weighed to the nearest $0.01 \mathrm{~g}$ to determine the decayed weight (W2). Weight loss was calculated as percentage of the initial weight.

$$
\text { weight loss }(\%)=[(W 1-W 2) / W 1] \times 100)
$$

\section{Identification of Extract Components}

The pure walnut heartwood extract was separated and dried under nitrogen gas to give pale red colored extracts at $12 \%$ yield, based on oven dried weight of the heartwood. In order to identify the components present in the extracts, about $1 \mathrm{mg}$ (powder) extract was selected, mixed with 30 micro liter N,O-bis (trimethylsilyl) triflouroacetamide (BSTFA) $+1 \%$ timethylchlorosilane (TMCS) reagent and about 15 micro liter pyridine in test tube, then the test tube was placed in a water bath at $70{ }^{\circ} \mathrm{C}$ for one hour.

Extracts were analyzed using GC/MS on an Agilent 6890 Gas Chromatograph, equipped with a split/splitless injector and a 7963 Mass Selective Detector (MSD). The chromatography was performed on a HP-5MS capillary column (SGE, $30 \mathrm{~m}, 0.25 \mathrm{~mm}$ ) with helium as carrier gas, at $1 \mathrm{~mL} / \mathrm{min}$ flow. The temperature change was programmed between 60 and $260^{\circ} \mathrm{C}$, increasing at the rate of $6^{\circ} \mathrm{C} / \mathrm{min}$.

\section{Statistical Procedure}

To evaluate changes in measured property of untreated decayed, treated decayed, treated un-decayed, and untreated (un-decayed or control) specimens, one-way ANOVA analyses of variance was used. The effects of different concentrations of extractives on weight loss, density, and retention ratio are determined. Duncan's test was used for ranking of the average values of measured property (Table 2, and 3).

\section{RESULTS AND DISCUSSION}

The results from toxicity screening tests revealed that the walnut heartwood extract exhibits preservative potential toward non durable wood such as poplar wood in the experiment (Table 1). The fungal, Trametes versicolor (Tv), growth on untreated wood reached almost 100\%. However, applying increasing concentrations of walnut extracts reduced the growth. Applying $0.15 \mathrm{mg} / \mathrm{mL}$ solution, TV showed a growth reduction of at least $27.91 \%$. Therefore, the relative toxicity threshold was estimated to 
be about $0.15 \mathrm{mg} / \mathrm{mL}(150 \mathrm{ppm})$ for $T v$ in ethanol-toluene solvent. Of course, this was not unexpected, because it has been reported that the concentration of $200 \mathrm{ppm}$ juglone has been reported to cause $72.1 \%$ inhibition of white-rot fungus (Pleurotus sajor-caju) (Currelli et al. 2001).

Table1. The Fungal Growth under Various Concentrations of Walnut Heartwood Extracts

\begin{tabular}{|c|c|c|}
\hline \multirow{2}{*}{$\begin{array}{c}\text { Extract Concentration } \\
(\mathrm{mg} / \mathrm{mL} \text { solvent })\end{array}$} & \multicolumn{2}{|c|}{$\begin{array}{c}\text { Growth Rate } \\
(\% \text { of Specimen Area) }\end{array}$} \\
\cline { 2 - 3 } & Ethanol-Toluene & Toluene \\
\hline 0 & 100 & 100 \\
\hline 0.0015 & 100 & 100 \\
\hline 0.003 & 100 & 97 \\
\hline 0.075 & 56.46 & 82 \\
\hline 0.15 & 27.91 & 65 \\
\hline
\end{tabular}

Since the toxicity screening demonstrated that the concentration of $1.5 \%$ extract in ethanol-toluene resulted in the lowest growth, this concentration and higher levels were selected for further decay tests on wood. The average and standard deviation of weight loss measurements are summarized in Table 2. Statistical analysis showed that the effect of extract solution concentration on weight loss was significant at the $5 \%$ level. Consequently, the ranking of the average values using Duncan test is provided in Table 2 by lower case letters.

Table 2. The Average and Standard Deviation Values of Weight Loss and Extractive Retention Ratio of Poplar Wood

\begin{tabular}{|c|c|c|}
\hline Specimen Condition & Weight Loss (\%) & Retention Ratio (\%) \\
\hline Decayed (Untreated) & $36.96^{\mathrm{c}} \pm 1.64$ & - \\
\hline Decayed (Treated, 1.5\%) & $30.40^{\mathrm{a}} \pm 2.11$ & $1.99^{\mathrm{a}} \pm 0.33$ \\
\hline Decayed (Treated, 2.5\%) & $34.50^{\mathrm{bc}} \pm 1.06$ & $3.67^{\mathrm{ab}} \pm 1.02$ \\
\hline Decayed (Treated, 3.5\%) & $32.44^{\mathrm{ab}} \pm 2.96$ & $5.32^{\mathrm{b}} \pm 1.90$ \\
\hline
\end{tabular}

* Superscripts, lower case letters, indicate Duncan ranking of the average value of measured weight loss

Table 3. The Average and Standard Deviation Values of Dry Density of Poplar Wood Specimens

\begin{tabular}{|c|c|c|}
\hline \multirow{2}{*}{ Specimens Condition } & \multicolumn{2}{|c|}{ Dry Density $\left(\mathrm{gr} / \mathrm{cm}^{3}\right)$} \\
\cline { 2 - 3 } & untreated & Treated \\
\hline $\begin{array}{c}\text { Untreated and } \\
\text { un-decayed (Control) }\end{array}$ & $0.387^{\mathrm{abc}} \pm 0.006$ & - \\
\hline Decayed (Untreated) & $0.367^{\mathrm{a}} \pm 0.006$ & - \\
\hline Decayed (Treated, 1.5\%) & $0.417^{\mathrm{bc}} \pm 0.035$ & $0.420^{\mathrm{c}} \pm 0.030$ \\
\hline Decayed (Treated, 2.5\%) & $0.377^{\mathrm{a}} \pm 0.021$ & $0.380^{\mathrm{ab}} \pm 0.020$ \\
\hline Decayed (Treated, 3.5\%) & $0.377^{\mathrm{a}} \pm 0.006$ & $0.387^{\mathrm{abc}} \pm 0.006$ \\
\hline
\end{tabular}

*Superscripts, in lower case letters, indicate Duncan ranking of the average value of measured dry density 
The mean weight loss values obtained from the decay test were $36.96 \%$ for untreated specimens and $30.40 \%, 34.50 \%$, and $32.44 \%$ for treated poplar wood specimens impregnated with $1.5 \%, 2.5 \%$, and $3.5 \%$ extractives solutions, respectively (Table 2). It is interesting to note that specimens impregnated with the solution containing $1.5 \%$ extract showed the lowest weight loss, even though the retention ratio of the extract was lowest at this concentration (Table 2). Nevertheless, we tried to use randomly selected specimens with similar density, but the density of samples treated with $1.5 \%$ solution was higher and therefore more resistant toward fungus. The dry density gain after treatment of these specimens treated with solutions containing either $1.5 \%$ or $2.5 \%$ extract is almost the same and for the other specimens is almost four times higher (Table 3). Surprisingly, the average untreated dry density of specimens impregnated with solution containing $1.5 \%$ extract was higher than other specimens, which inhibited the penetration of fungus mycelium and consequently lower deterioration and weight loss.

The Willeitner scale showed distinct evidence of fungal colonization (100\%) on the specimens surfaces (Willeitner 1984). However, extractives treatment reduced the fungal growth (67\% colonization) to a noticeable extent (Fig. 2).
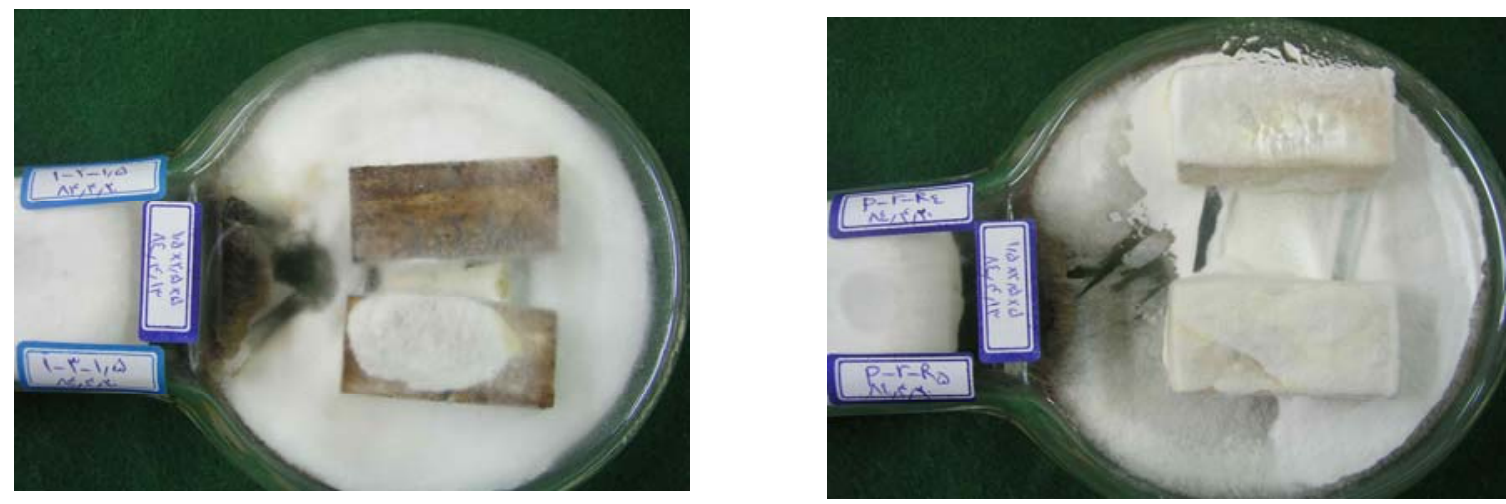

Figure 2. Mycelium growth of Trametes versicolor fungus on treated specimens with $1.5 \%$ extractives solution and decayed (left), and the untreated decayed specimens (right)

Even though decay by white-rot fungus was evident on untreated specimens and those treated with 3 concentrations of extractives, the penetration of extractives into the treated poplar wood specimens provided some protection against white-rot fungus.

The result of the analysis of walnut heartwood extractives is presented in Table 4. Gallic acid, D- fructose,1,3,4,5,6-pentakis-o-(hydroxyl), D-glucose,2,3,4,5,6-pentakiso-(hydroxyl), and xylitol 5-TMS are present. In addition, 2,7-dimethylphenantheren as an important component of the extractives was detected, and its presence in walnut heartwood extract has not been reported previously. 2,7-dimethylphenantheren-like compounds (naphthalene) have been reported in the fruit extracts of Juglans regia L. (Talapatra et al. 1988; Muller and Leistner 1978). The heartwood extractives also contained minor quantities of $\alpha$-pinene and juglone. 
Table 4. Composition (area \%) of the Walnut Heartwood (Juglans regia L.) Extractives

\begin{tabular}{|l|c|c|}
\hline Components & $\mathrm{RT}(\mathrm{min})$ & Heartwood \\
\hline a-pinene & 5.69 & 5.28 \\
\hline Juglone & 6.02 & 5.15 \\
\hline propanoic acid, 2-[(trimethylsilyl)oxy]-, trimethyl & 8.69 & 1.07 \\
\hline silane, trimethyle (phenylmethoxy) & 10.66 & 1.33 \\
\hline 3,7-dioxa-2,8-disilanonane, 2,2,8,8-tetramethyl & 13.34 & 2.40 \\
\hline 3,8-dioxa-2,9-disiladecane, 2,2,9,9-tetramethyl & 17.81 & 2.15 \\
\hline 2,7-dimethylphenantheren & 19.99 & 5.81 \\
\hline xylitol 5-TMS & 21.37 & 3.26 \\
\hline benzoic acid,3,4-bis(hydroxyl) & 22.67 & 2.06 \\
\hline d-fructose,1,3,4,5,6-pentakis-o-(hydroxyl) & 22.87 & 0.79 \\
\hline d-glucose,2,3,4,5,6-pentakis-o-(hydroxyl) & 23.94 & 4 \\
\hline Benzoic acid,3,4,5-tri(hydroxyl)/Gallic acid & 24.72 & 44.57 \\
\hline
\end{tabular}

\section{CONCLUSIONS}

1. Analysis of variance and Duncan's test (Table 3) indicated that the dry density of treated specimens impregnated with a solution containing $1.5 \%$ extract was significantly different from specimens before treatment. This difference was attributed to lower weight loss of these specimens, which was significantly different from other decayed specimens. On the other hand, the dry density of specimens treated with a solution of $3.5 \%$ extract was not significantly different from other decayed specimens, except for those treated with $1.5 \%$ concentration. Furthermore, the weight loss of specimens treated with solution of $3.5 \%$ extract was significantly different from the control decayed specimens. Thus it can be concluded that at higher concentration of extractives, fungal resistance of treated poplar wood specimen is higher. This can be attributed to the antimicrobial potential of extractive components such as gallic acid, 2,7dimethylphenantheren, and juglone. Such compounds have anti-fungal toxicity and can serve as wood preservatives. The effect of extractives to impose lower weight loss was maximized using solution of $3.5 \%$ extract.

2. The precipitation of extractives in the cell lumens and the cell wall introduces weight gain (density gain) in poplar wood specimens, and consequently reduces the weight loss of the wood.

3. Gallic acid probably can be extracted from any walnut wood. Analysis of the walnut heartwood extractives indicated that these extractives can provide a major natural source of gallic acid and 3,7-dioxa-2,8-disilanonane,2,2,8,8-tetramethyl. The juglone and 2,7-dimethylphenantheren were found to occur as minor constituents in the walnut heartwood extractives. 


\section{REFERENCES CITED}

ASTM D 1107-96 (1998). "Standard test method for ethanol-toluene solubility of wood," Philadelphia, PA., USA.

Bhargava, U. C. (1967). "Pharmacology of ellagic acid from black walnut," Ph.D thesis, Univ Miss, $366 \mathrm{p}$.

Bhargava, U. C., and Westfall, B. A. (1968). "Antitumor activity of Juglas nigra (black walnut) extractives," J. Pharm. Sci. 57(10), 1674-1677.

British Standard 838. (1961). "Methods of test for toxicity of wood preservatives to fungi," BSI, London.

Chang, S. T., Wang, S. Y., Wu, C. L., Su, Y. C., and Kuo, Y. H. (1999). “Antifungal compounds in the ethyl acetate soluble fraction of the extractives of Taiwania (Taiwania cryptomerioides Hayata) heartwood," Holzforschung 53, 487-490.

Curreli, N., Soliai, F., Massa, L., Comandini, O., Rufo, A., Sanjust, E., Rinaldi, A., and Rinaldi, A. C. (2001) "Effects of plant-derived naphtoquinones on the growth of Pleurotus sajor-caju and degradation on the compounds by fungal culture," Journal Basic Microbiol. 41 5, 253-259.

Da Costa, E. W. B., Rudman P., and Gay, F. J. (1958). "Investigations on the durability of Tectona grandis," Empire Forestry Review 37, 291-298.

Gottlieb, O. R., and Yoshida, M. (1989). "Lignans," In: Natural Products of Woody Plants: Chemical Extraneous to the Lignocellulosic Cell Wall," Rowe, J. W. (ed.), Springer-Verlag, Berlin, Chapter 7.3, 439-511.

Gupta, S. R., Ravindranah, B., and Seshari, T. R. (1972). "Juglandaceae: Polyphenols of Juglans nigra," Phytochem. 11, 2634-2636.

Hart, J. H. (1989). "The role of wood exudates and extractives in protecting wood from decay," In: Rowe, J. W. (ed.), Natural Products of Woody Plants, Springer-Verlag Co., Berlin, pp. 861-878.

Kai, Y. (1991). “Chemistry of extractives,” In: Hon, D. N. S., Shiraish, N. (eds.), Wood and Cellulosic Chemistry, Marcell Dekker Inc., New York, 215-255.

Kishino, M., Ohi, H., and Yamaguchi, A. (1995). "Characteristics of methanol extractives from Chengal wood and their antifungal properties," Mokuzai Gakkaishi 41, 444447.

Kondo, R., and Imamura, H. (1986). "Antifungal compounds in heartwood extractives of hinoki (Chamaecyparis obtusa Endl.)," Mokuzai Gakkaishi 32, 213-217.

Lebow, S. T., and Tippie, M. (2001). "Guide for minimizing the effect of preservative treated wood on sensitive environments," General Technical Report FPL-FTR-122. USDA.

McGranahan, G., and Leslie, C. (1991). "Walnuts (Juglans L.)," In Moore, J. N., and Ballington, J. R. (eds.), Genetic Resources of Temperate Fruit and Nut Crops, International Society for Horticultural Science, Wageningen, 907-951.

Morita, S. I., Hidaka, T., and Yatagai, M. (1997). "Antifungal compounds of the extractives of Yakusugi (Crypromeria japonica D. Don)," Wood Preserv. 23, 11-19. 
Nzokou, P., and Kamdem, D. P. (2002). "Evaluation of extractives from African Padauk (Peterocarpus soyauxii Taub.) for protection of non decay resistant species," $33^{\text {rd }}$ Annual Meeting, Cardiff, South Wales, U. K. No. IRG/WP/02-10419. Inter. Res. Group on wood preservation, Stockholm, Sweden.

Reyes-Chilpa, R., Gomez-Garibay, F., Moreno-Torres, G., Jimenez-Estrada G., and Quiroz-Vasquez, R. I. (1998). "Flavonoids and isoflavonoids with antifungal properties from Platymiscium yucatanum heartwood," Holzforchung 52(5), 459-462.

Rudman, P., and Da Costa, E. W. B. (1959). "Variation in extractive content and decay resistance in the heartwood of Tectona grandis," Journal of the Institute of Wood Science 3, 33-42.

Rudman, P. (1963). "The causes of natural durability in timber: Part XI. Some tests on the fungi toxicity of wood extractives and related compounds," Holzforschung 17(2), 54-57.

Rudman, P. (1965). "The causes of natural durability in timber: XVIII. Further notes on the fungi toxicity of wood extractives," Holzforschung 19, 57-58.

Scheffer, T. C., and Cowlling, E. B. (1966). "Natural resistance of wood to microbial deterioration," Ann. Rev. of Phytopathol. 4, 147-170.

Scheffer, T. C., and Morrell, J. J. (1998). "Natural durability of wood: A worldwide checklist of species," Forest Research Laboratory, Oregon State University. Research Contribution 22, 58p.

Schultz, T. P., Hubbard, T. F., Jin, J. L., Fisher, T. H., and Nicholas, D. D. (1990). "Role of stilbene in the natural durability of wood: Fungicidal structure-activity relationships," Phytochemistry 29, 1501-1507.

Schultz, T. P., Harmes, W. B., Fisher, T. H., McMartrey, K. D. Minn, J., and Nicholas, D. D. (1995). "Durability of Angiosperm heartwood: The importance of extractives," Holzforschung 49, 29-34.

Schultz, T. P., and Nicholas, D. D. (2000). "Naturally durable heartwood: Evidence for purposed dual defensive function of extractives," Phytochemistry 54, 47-52.

Soderquist, C. J. (1973). "Juglone and allelopathy," J. Chem. Educ. 50(11), 782-783.

Steber, B. (2000). "Marketing of teak," Proceedings of the Seminar on high value timber species for plantation establishment- Teak and Mahoganies, JIRCAS Report, n’16, 83-90.

Stevanovic-Janezic, T., Cooper P. A., and Tony Ung, Y. (2001). "Chromated arsenate preservative treatment of North American hardwoods," Holzforschung 55(1), 7-12.

Talapatra, S. K., Karmacharya, B., and Talabatra, B. (1988). "Levoregiolone an alphatetralone from Juglans regia; Structure, Stereochemistry and confirmation," Phytochemistry 3929 p.

Thevenon, M. F., Roussel, C., and Haluk, J. P. (2001). "Possible durability transfer from non-durable wood species," The study case of teak wood Paper presented at the International Research Group on Wood Preservation (IRG), Nara, Japan, 20-25 May.

Thomasson, G., Capizzi, J., Dost, F., Morrell, J. J., and Miller, D. (2002). "Wood preservation and wood products treatment training manual," This publication was revised from a University of Georgia Cooperative Extension Service Publication. 
TS 2476 (1976). "Odunda fiziksel ve mekaniksel deneyler icin numune elde etme metotları ve genel ozellikler," Türk Standartları Enstitüsü (TSE), Ankara.

Wang, S. Y., Chen, P. F., and Chang, S. T. (2005). "Antifungal activities of essential oils and their constituents from indigenous cinnamon (Cinnamomum osmophloeum) leaves against wood decay fungi," Bioresour. Technol. 96, 813-818.

Waterman, M. A. (1946). "The effect of water soluble extractives from the heartwood of tropical American woods on the growth of two wood decay fungi," Tropical Woods $88,1-11$.

Westfall, B. A., Russell, R. L., and Auyong, T. K. (1961). "Depressant agent from walnut hulls," Science 134, 1617-1618.

Willeitner, H. (1984). "Laboratory tests on the natural durability of the timber methods and problems," Document International Research Group on Wood Preservation. IRG/WP/2217.

Article submitted: August 25, 2010; Peer review completed: September 16, 2010;

Revised version received: November 6, 2010; Accepted and Published: November 15, 2010 . 